\title{
EDUCATION OF CHILDREN WITH DISABILITIES IN NONFORMAL LEARNING ENVIRONMENTS: A CROSS- DISCIPLINARY APPROACH OF STEAM EDUCATION IN A TECHNOLOGICAL MUSEUM IN GREECE
}

\author{
Charikleia Kanari ${ }^{1}$, \\ Anastasia Zoi Souliotou ${ }^{2 \mathrm{i}}$ \\ 1University of Thessaly, \\ Greece \\ 2International Hellenic University, \\ University of Western Macedonia, \\ Greece
}

\begin{abstract}
:
In recent years there is an increasing interest about STEAM (Science, Technology, Engineering, Arts \& Mathematics) model in education. STEAM is a cross-disciplinary approach which breaks down the barriers among disciplines, offers a dynamic character in teaching and sheds light on various aspects of the aforementioned parts of STEAM equation with multiple benefits for all children including those with disabilities. Furthermore, the increasing interest and the development of museum educational programs for school groups provide unique opportunities in STEAM education that are not available in schools. The museum as nonformal learning environment and its exhibits, the qualitative characteristics of learning and the wide range of the expected learning outcomes enrich the design and implementation of STEAM educational programs providing meaningful learning experiences for all children. The present paper refers to a cross-disciplinary approach which connects STEAM education, Museum Education and Special Education for the design and implementation of an educational program for a school group of children with disabilities. The educational program "Making mosaics with bricks and colors" was based on a. the STEAM approach, b. the characteristics of learning in the museum, c. the principles of Differentiated Instruction (DI) and Universal Design for Learning (UDL), and d. the unique characteristics of a thematic technological museum for the industrial heritage in Greece where the educational program took place. Based on the experience of the implementation of the educational program and the qualitative data of the evaluation of the program, it is argued that STEAM education as well as collaborations between different specialists and between schools and museums provides meaningful learning experiences to all children including those with disabilities.
\end{abstract}

i Correspondence: email asouliotou@gmail.com 
EDUCATION OF CHILDREN WITH DISABILITIES IN NONFORMAL LEARNING ENVIRONMENTS: A CROSS-DISCIPLINARY APPROACH OF STEAM EDUCATION IN A TECHNOLOGICAL MUSEUM IN GREECE

Keywords: STEAM education, museum education, special education, nonformal learning environments, visual arts

\section{Introduction}

In the $21^{\text {st }}$ century education and knowledge are recognized as common goods (UNESCO, 2015) and learning is perceived as a "lifetime and lifewide" process (Norqvist \& Leffler, 2017, p. 236) which occurs in different environments and authentic contexts -formal, nonformalii and informal (Grajcevci \& Shala, 2016; Norqvist \& Leffler, 2017). Learning does not only refer to acquisition of knowledge and skills but mainly to the personal development (Hooper-Greenhill, 2004) and from a socio-cultural point of view to the ability and the right for participation in diverse social contexts and practices (Moss, 2003). In this framework there is a strong emphasis on the right of access and participation of all people in education and knowledge and especially of vulnerable social groups or groups at risk of social exclusion (UNESCO, 2015). Furthermore, the vast changes of the contemporary society are increasingly turning the attention of many researchers to the importance of the "21 st century skills": creativity, critical thinking, problem solving, collaborative working, information and communication literacy and skills, etc. (Bell, 2010; Bellanca \& Brant, 2010; Black, 2012; Zayyad, 2019). Thus, theoretical frameworks, educational approaches and practices that promote interdisciplinary approaches, participation, access and active engagement of all people in the learning process in different educational and learning environments are major topics of discussion and relevant researches, practices and policies.

Many researchers have underlined the importance of STEAM (Science, Technology, Engineering, Arts \& Mathematics) education in providing children and citizens with skills -including $21^{\text {st }}$ century skills- as well as habits of mind and hand that highly contribute to their global literacy in the 21st century (Bati, Yetişir, Çalişkan, Güneş \& GülSaçan, 2018; Gess, 2017; Land, 2013; Zayyad, 2019). Furthermore, over the past decades the educational role of other institutions (e.g. museums) has been a topic of intensive research and relevant practices (Argyropoulos \& Kanari, 2019; Black, 2012; Griffin, 2007; Hooper-Greenhill, 2007; Kanari, 2015; Nikonanou, 2010; Vartiainen \& Enkenberg, 2013). STEAM as well as STEM (Science, Technology, Engineering \& Mathematics) education is not provided only in formal education, but also out of the school in nonformal learning environments including museums, science centers, etc. (Corner, 2016; Falk et al., 2016; Grant \& Patterson, 2016; Stauset al., 2020). The range of museum collections, the opportunities for direct experience, learning and engagement with objects, the development of educational programs with cross-curricular themes, the characteristics of museums as nonformal environments, as described in the following

\footnotetext{
ii In general, the term nonformal education refers to planned activities out of formal education, as for example structured educational visits in museums and the museum educational programs for school groups (field trips), (Eshach, 2007; Black, 2012; Romi \& Schmida, 2009). For further definitions of nonformal educational programs and informal learning see UNESCO-UIS, 2012.
} 
sections, the social dimension of the museum learning and experience (Ambrose \& Paine, 2018; Falk \& Dierking, 2013; Hein, 1998; Hooper-Greenhill, 1999, 2007; Nikonanou, 2010), enrich and provide opportunities for implementation of STEAM education programs with particular characteristics. These characteristics are different from those of schools, in relation to various disciplines of museum collections and exhibitions or even in relation to museums functions ${ }^{\text {iii. }}$

The aforementioned issues are of particular importance for all children including those with disabilities. It is argued that STEAM education has multiple benefits for children with disabilities (Butera, Horn, Palmer, Friesen \& Lieber, 2016; Hwang \& Taylor, 2016; Zayyad, 2019). As Maslyc (2016, p.112-113) asserts "STEAM learning and making are for everyone. The inclusion of this practice makes learning accessible for any student with a disability". In addition, the role of nonformal learning environments in the education of children with disabilities, as for example museums, has been stressed by many researchers who underline the multiple benefits for children with various disabilities and in relation to different education domains (Argyropoulos \& Kanari, 2019; Golding, 2012; Hooper-Greenhill, 2007; Kanari, 2015; Lurio, 2016; Pearson \& Aloysious, 1994; Shelley, 2015). However, in order to respond to the heterogeneity of students' population, including those with disabilities and/or special educational needs, it is crucial to adopt and implement principles and practices of theoretical frameworks that have been developed in order to provide to all learners opportunities for equal access and engagement in the learning process. Such theoretical frameworks are Differentiation Instruction (Gregory \& Chapman, 2007; Tomlinson, 2001) and Universal Design for Learning (CAST, 2018). Principles of these theoretical models are both used or should be used not only in formal educational settings but also in nonformal learning environments (Argyropoulos \& Kanari, 2019; Fletcher, 2013; Nikolaraizi, Kanari \& Marschark, 2020; Rappolt-Schlichtmann \& Daley, 2013; Shepherd, 2009).

The present paper draws on the aforementioned educational theoretical approaches and practices. More precisely, it refers to a cross-disciplinary approach which brings together STEAM Education, Museum Education and Special Education for the design and implementation of an educational program for a school group of children with disabilities in a thematic technological museum for the industrial heritage in Greece. The sections below present the theoretical framework of the educational program, the design and implementation stages and its evaluation based on qualitative data.

\section{Literature Review}

As stated above, the present paper refers to the case of a museum educational program based on STEAM education approach for a school group of children with disabilities in a technological museum. The theoretical background is structured in the following axes:

\footnotetext{
iii See for example the case of a teacher workshop regarding STEAM and art conservation of the Smithsonian American Art Museum (https://americanart.si.edu/videos/get-steamed-art-conservation-161341, Access 19 June, 2020).
} 
EDUCATION OF CHILDREN WITH DISABILITIES IN NONFORMAL LEARNING ENVIRONMENTS: A CROSS-DISCIPLINARY APPROACH OF STEAM EDUCATION IN A TECHNOLOGICAL MUSEUM IN GREECE

a. STEAM education and the benefits for children with and without disabilities, $b$. Museum Education and learning in museums as nonformal learning environments, $c$. the relationship between schools and museums and the benefits for all children including those with disabilities, and $\mathrm{d}$. the theoretical framework of Differentiated Instruction and Universal Design for Learning.

\subsection{STEAM Education and children with and without disabilities}

STEAM or ST $\sum @ M$ (Yakman, 2008) comes from adding the arts into the traditional STEM and derives from the need to enhance self-expression, self-motivation, curiosity, creativity and innovative thinking in education (Bazler \& Sickle, 2017; Chang \& Lee, 2019; Land, 2013; Quigley, Herro, Jamil, 2017). STEAM is considered as a way of promoting innovation through creative thinking and innovative art and design practices alongside technology (Land, 2013). Both art and STEM share de facto and a priori common fields with regards to knowledge, as for example the patterns which relate to arts as well to geometry and mathematics (Khine \& Areepattamannil, 2019). Moreover, STEM practices have the objective to come up with discovery which, in turn, is enabled through creativity (Sousa \& Pilecki, 2013). According to Ko, An and Park (2012), the need to bring together the arts with science and other STEM fields lies in this particular point of filling the gap of STEM which lacked of creativity as well as that of the arts which lacked of logic. Thus, arts integration in STEM disciplines is essential and fosters: not only problem solving, but also creativity and problem seeking; not only tasks execution, but also a multifarious exploration of any idea or concept. Furthermore, the arts largely invigorate the STE(A)M platform also by making STEM more attractive and appealing to students and graduates, which is a way to encourage them to follow careers in STEM (Conner, 2016; Ko, An, Park, 2012; Yakman, 2008). However, the arts' role is not limited to that of a vehicle to reach STEM or to make STEM more appealing. The arts are an integral part of human civilization and a way to identify ourselves as well as the environment and what surrounds us. Arts provide opportunities, among others, for: exploring various subjects in different ways; realizing creative activities; strategic and critical thinking; the development of various skills (Butera et al., 2016; Land, 2013; Quigley, Herro, Jamil, 2017) especially through a "personal dialogue between the eyes, mind and hands" (Sickle \& Bazler, 2017, p. xix). Thus, the STEAM approach should also be regarded as a way to reach humanity by going deep into social issues and by using all parts of the STEAM equation in favor of different social groups.

Studies regarding arts in education underline a range of multiple benefits and outcomes for children with and without disabilities through and beyond STEAM education (Butera et al., 2016; Liao, 2016; Malley, \& Silverstein, 2014; Perignat \& KatzBuonincontro, 2019; Sousa \& Pilecki, 2013). STEAM approach responds to the "integrated nature of learning and teaching" (Butera et al. 2016, p.145) through a range of approaches (Chang \& Lee, 2019) providing opportunities for instruction and activities that motivate children, enhance their engagement in the learning process and permits the crossdisciplinary and spherical approach of a concept (Gess, 2017). STEAM education is a 
learner-centered approach and instruction (Zayyad, 2019) which is in line with contemporary educational approaches that place the emphasis on active engagement of each learner and recognizes that children learn in different ways (Butera et al., 2016; Gregory \& Chapman, 2007; Tomlinson, 2001; Zayyad, 2019). The multisensory nature of the STEAM approach, the hands-on activities, the experiential learning and real word experiences, the opportunities for exploration in relation to different scientific subjects (e.g. mathematics, science, etc), the use of tactile and manipulative tools and materials in combination with creative art activities (visual arts, music, dance, dramatic play), has multiple benefits for all children (Butera et al., 2016; Gess, 2017; Maslyk, 2016). STEAM education benefits children with various disabilities and/or special educational needs including poor readers, children with speech and language disorders, learning disabilities, specific learning disorders, children with sensory disabilities (blind and visually impaired $^{\text {iv }}$, deaf and hard of hearing), children with autism spectrum disorders, etc., or foreign language children (Butera et al., 2016; Hwang \& Taylor, 2016; Maslyk, 2016; Zayyad, 2019). STEAM education provides opportunities for children's active engagement in the learning process and also multiple ways to demonstrate what they have learned or what they are able to do beyond the written assignments and textbooks (Maslyk, 2016).

Among the benefits of STEAM education for children with disabilities and/or special educational needs are: the connection of various concepts with tangible experiences and materials; the development of various skills (language, academic, social, communication, fine motor skills, etc.); the engagement with new technologies; the real world problem-solving through the connection with arts and the generalization of connecting the arts with science content; the motivation; the enhancement of self-esteem and confidence; the creativity; the improvement of peer interaction and cooperation, etc. (Hwang \& Taylor, 2016; Maslyk, 2016; Zayyad, 2019). The latter one is of great importance both in special and inclusive educational settings (Hwang \& Taylor, 2016). According to Butera et al. (2016), activities which are designed in a way that promotes cooperative working and social interaction of children, including STEAM activities, contribute to the development of social skills which is a very important domain of education for children with disabilities.

As mentioned above, STE(A)M education is not provided only in formal educational settings, but also in nonformal learning environments including museums (Corner, 2016; Falk et al., 2016; Staus et al., 2020). The learner-centered approach in STEAM education (Zayyad, 2019), the audience-centered approach within museums (Black, 2005, 2012), the qualitative characteristics of learning in museums (HooperGreenhill, 2007; Hein, 1998; Nikonanou, 2010) and the long and strong relationship between schools and museums (Ambrose \& Paine, 2018; Black, 2012; Hooper-Greenhill, 2007; Griffin, 2007; Nikonanou, 2010), compose an interesting and growing field of research and practices for all children including those with disabilities.

iv See for example also the website of Perkins School for the Blind for STEM activities https://www.perkinselearning.org/topics/stem (Accessed 28 April, 2020). 
EDUCATION OF CHILDREN WITH DISABILITIES IN NONFORMAL LEARNING ENVIRONMENTS: A CROSS-DISCIPLINARY APPROACH OF STEAM EDUCATION IN A TECHNOLOGICAL MUSEUM IN GREECE

\subsection{Museum Education and learning in museums as nonformal learning environments}

Museum Education constitutes a field of intensive discussion, research, studies and practices under the influence of social changes, the development of human and social sciences as well as theories for the intelligence, knowledge and learning (Black, 2005, 2012; Hein, 1998, 2006; Hooper-Greenhill, 1999, 2007). In this framework the concept of education and learning has been redefined focusing on the multidimensional nature of learning in terms of process and outcomes (Black, 2012; Hooper-Greenhill, 2006, 2007) and also in terms of the "systemic, context-bound nature of learning" (Vartiainen \& Enkenberg, 2013, p.841) which occurs in different environments, contexts and settings during life time (Gibbs, Sani, \& Thompson, 2007; Grajcevci \& Shala, 2016; Nikolaraizi, Kanari \& Marschark, 2020; UNESCO, 2015).

Much of the relevant literature in the field of museum studies points out the specific characteristics of learning in the museum (Hein, 1998; Hooper-Greenhill, 2006, 2007; Nikonanou, 2010) and the "power of museum pedagogy" which is based on the very concept of the "experience" (Hooper-Greenhill, 2006). Many researchers have studied issues of learning in museums as lifelong, informal or/and nonformal learning environments where a range of less or more structured activities and programs take place for different audiences and target groups (Black, 2012; Gibbs, Sani, \& Thompson, 2007; Hein, 1998; Hooper-Greenhill, 2007; Nikonanou, 2010; Vartiainen \& Enkenberg, 2013). Compared to formal education settings, learning in museums is more open-ended, flexible and potentially more responsive to different learning styles and learners (Hooper-Greenhill, 2007). The absence of curriculum and formal assessment systems, the range of methods and tools that are used within museums, the social interaction (Black, 2012; Falk \& Dierking, 2013; Hein, 1998; Hooper-Greenhill, 2007), the "object based experience" (Hooper-Greenhill, 2007, p. 37) in contrast to textbooks which are used in formal education (Vartiainen \& Enkenberg, 2013), are among the most important qualitative characteristics of learning in museums.

In the context of an audience-centered approach and taking into account that the ultimate aim is the meaningful engagement of museum visitors with the exhibits and the learning process (Black, 2005, 2012), much of the attention, among others, has been given to the expected learning outcomes as a result of the learning process within museums as learning and social environments. The conceptual framework of the Generic Learning Outcomes (GLOs) that has been developed within museum environments includes the following categories: "knowledge and understanding, skills, attitudes and values, enjoyment, inspiration and creativity, activity, behaviour and progression" (Hooper-Greenhill, 2007:5357). More analytically "knowledge and understanding" refers to different subjects or connections between specific subjects, artifacts, etc, (e.g. history, art, etc), to different sites or more local and personal matters (e.g. family), to the learners' prior knowledge and experiences and to different ways that people learn and develop their understanding. "Skills" include a range of different skills such as cognitive skills, physical, practical skills, social skills, etc., like communicating or working in teams, emotional skills, empathy, etc. "Attitudes and values" are towards ourselves, other people (e.g. self-esteem, 
understanding of diversity, etc) or even towards museums as cultural spaces. The outcomes of "enjoyment, inspiration and creativity" underline the significance of enjoyment in the learning process and include aspects such as motivation, personal achievement, etc. Finally, the fifth category of GLOs, "activity, behavior and progression" refers to a range of actions as a result of learning and describes other aspects of learning, as for example the desire for further learning, repeating visits in museums, etc. (Hooper-Greenhill, 2002, 2004, 2007; Moussouri, 2002). In addition, museums have an important educational role for providing opportunities for the development of $21^{\text {st }}$ century skills (Black, 2012). Among these skills are: the "learning and innovation skills" (e.g. critical thinking, problem solving, creativity and working creatively with other people, communication and collaborative skills, literacy, etc); "information, media and technology skills" (e.g. information, communication and technology literacy, global awareness, civic, environmental, health literacy, etc); "life and career skills" (e.g. adaptability, flexibility, working independently and in different teams, collaborating in different teams, productivity, responsibility, etc.) (Institute of Museum and Library Services, 2009, p. 2325).

Furthermore, many researchers have stressed the importance of the social role of museums. Museum education is strongly linked to the social impact and responsibility of museums (Hein, 2006). The role of museums towards the enhancement of social inclusion has been a topic of research and studies (Dodd \& Sandell, 2001; HooperGreenhill, Sandell, Moussouri \& O'Riain, 2000; Sandell, 2002, 2003). Dodd and Sandell (2001) describe different levels of museums' social impact towards social inclusion: the individual level, the community and the wider societal level. In this framework, outputs and objectives, as for example the enhancement of self-esteem, the sense of belonging, the creativity, the acquisition of new skills and knowledge, the inspiration, the empowerment of communities, the participation in local community, the promotion of a better understanding of the diversity, the elimination of stereotypes, prejudices and discrimination, etc, enhance social inclusion and cohesion in many different ways and levels (Dodd \& Sandell, 2001; Sandell, 2002). Although museums have different resources to promote relevant practices and collaborations, it is widely accepted that museums are more and more aware of this role and develop a wide range of activities and programs towards this direction (Coxall, 2006; Dodd \& Sandell, 2001; Hansen, 2014; HooperGreenhill, Sandell, Moussouri \& O'Riain, 2000; Sandell, 2002, 2003).

All the aforementioned aspects of the educational and social role of the museum affect different people, audiences and target groups with multiple benefits for all. Furthermore, it seems that museum environment is a safe, flexible, creative and fruitful environment for persons who face different difficulties in formal educational settings, have less opportunities or are at risk of social exclusion (Hooper-Greenhill, 2006, 2007; Hooper-Greenhill et al. 2000; Tranter \& Palin, 2004). These issues are of particular importance for all children including those with disabilities. The complementary role of museums and nonformal learning environments in formal education and the conjunction of Museum Education and Special Education constitute a cross-disciplinary research field 
EDUCATION OF CHILDREN WITH DISABILITIES IN NONFORMAL LEARNING ENVIRONMENTS: A CROSS-DISCIPLINARY APPROACH OF STEAM EDUCATION IN A TECHNOLOGICAL MUSEUM IN GREECE

with multiple aspects related to education, learning, educational and social inclusion (Argyropoulos \& Kanari, 2019; Kanari, Argyropoulos \& Filippatou, 2017; Kanari, 2015).

\subsection{Schools-Museums relationship and the benefits for children with disabilities}

School groups are among the most important target groups for museums. The relationship between schools and museums has been a major topic of relevant researches, studies and practices (Ambrose \& Paine, 2018; Black, 2012; Hooper-Greenhill, 2007; Griffin, 2007; Nikonanou, 2010). Museum visits can complement formal education with multiple benefits for all children as well as for the school community (Black, 2013). According to Russel (2006 as cited in Black 2013:133) "children need the whole community and not just schools for learning and success in school, out of school, and in adult life after finishing the school". Indeed, museums around the world develop and offer educational programs for school children with topics linked to the curriculum, cross-curricular topics or themes in relation with contemporary and social issues. In this framework many researchers have stressed the important mediating role of teachers between school and museums. The aspects of this role include, among others: the connection of school visits in museums with the curriculum or across the curriculum; teachers' priorities and perceptions; their role with regards to pre-visit activities; the collaboration with the museum staff; issues of teachers' training in Museum Education, etc. (Argyropoulos \& Kanari, 2019; Black, 2005, 2012; Griffin, 2007; Hooper-Greenhill, 2007; Kanari, 2015; Nikonanou, 2010; Vartiainen \& Enkenberg, 2013;Vemi \& Kanari, 2008).

Regarding children with disabilities many researchers and professionals have underlined the role of nonformal learning environments and specifically of museums in the education of children with various disabilities and/or special educational needs (Argyropoulos \& Kanari, 2019; Golding, 2012; Hooper-Greenhill, 2007; Kanari, 2015; Lurio, 2016; Pearson \& Aloysious, 1994; Shelley, 2015). The specific qualitative characteristics of learning in museums (see, 2.2.), provide opportunities for meaningful learning and social experiences with multiple benefits for all children including those with disabilities and/or special educational needs. Many researchers, teachers and professionals have identified aspects of learning in museums such as the tangible and stimulating environment of museums, the hands-on activities, the sensory activities and learning through objects, the lack of competition and formal assessment systems, the activities with working in teams, etc, that motivate children with and without disabilities and enhance their participation and learning (Argyropoulos \& Kanari, 2019; Golding, 2012; Hooper-Greenhill, 2007; Pearson \& Aloysious, 1994). The above contribute to outcomes with regards to the enhancement of learning and understanding through the connection of various concepts with tangible experiences, the enhancement of memory, the development of a range of skills (e.g. literacy, academic, practical, social skills, etc), the increased motivation, the opportunities for personal achievement, the creativity, the self-esteem, etc. (Argyropoulos \& Kanari, 2019; Golden \& Walsh, 2013; Golding, 2012; Hooper-Greenhill, 2007; Melber \& Brown, 2008; Pearson \& Aloysious, 1994). Other researchers stress the importance of school visits in museums in relation to children's 
right for equal access to arts and culture and the enhancement of inclusive education and social inclusion (Aggelidis \& Avraamidou, 2011; Hayhoe, 2013; Kanari, Argyropoulos \& Filippatou, 2017; Spandagou, 2011). Thus, the collaboration between museums and schools as well as the development of various networks and forms of cooperation is very important (Argyropoulos \& Kanari, 2019; Argyropoulos et al., 2017; Argyropoulos, Nikolaraizi, Chamonikolaou \& Kanari, 2016; Hayhoe, 2013; Kanari, 2015; Kanari \& Vemi, 2012; Pearson \& Aloysious, 1994; Rosenberg, Schroder \& Wheelock, 2003).

It is important to note that all the above benefits should not be taken for granted, since they are not just a result of a museum visit. Issues of access for persons with disabilities and pedagogical methods and tools that promote the engagement of visitors - adults and children - are crucial factors for a rich learning and museum experience (Argyropoulos \& Kanari, 2019; Bounia, 2015; Kanari, 2015; Kanari \& Argyropoulos, 2014; Nikolaraizi, Kanari \& Marschark, 2020). The extended analysis of the multidimensional nature or access and the barriers that persons with disabilities face in the museums (e.g. physical, sensory, intellectual, emotional barriers, etc) (Resource, 2001; Weisen, 2008), is beyond the aims of the present paper. However, it is important to mention that the policy of access of persons with disabilities within museums should be considered as an ongoing, systematic and systemic approach and process (Weisen, 2008) in terms of quality and not just as a technical matter (Wapner, 2013). Furthermore, access is undoubtedly the necessary condition, but it is not identical to active involvement and engagement or to social inclusion (DCMS, 2000; Rappolt-Schlichtmann \& Daley, 2013; Spandagou, 2011). In order to respond to the heterogeneity of persons with disabilities and the diverse needs and characteristics of different persons - including children and school groups of children with and without disabilities - it seems that the principles of the theoretical approaches of Differentiated Instruction (DI) and Universal Design for Learning (UDL) are the most appropriate both in formal and nonformal learning environments including museums (Fletcher, 2013; Rappolt-Schlichtmann \& Daley, 2013; Shepherd, 2009).

\subsection{Differentiated Instruction and Universal Design for Learning}

The recognition of the diversity amongst students has led to the shift from "single-size instruction" (Tomlinson, 2001:2) to the development of theoretical frameworks that effectively address the diverse needs, abilities, readiness level, interests and characteristics of students' population including those with disabilities. The most widely known approaches are the Differentiated Instruction (DI) (Gregory \& Chapman, 2007; Tomlinson, 2001) and the Universal Design for Learning (UDL) (CAST, 2018). Both approaches recognize the heterogeneity of students' population, they are flexible and support adaptations and strategies in order to provide access, to engage and motivate students in the learning process and to provide opportunities and different ways to express what they have learned (Nikolaraizi, 2013). 
In short, DI refers to multiple ways and approaches for the differentiation of the following elements: a. the "content", i.e. what will be taught or what students are expected to learn and how they will have access to what we teach, b. the "process", i.e. how students will be engaged with the content, c. the "product", i.e. how students will demonstrate, rethink, use, apply or extend what they have learned, and d. the "learning environment", i.e. how the classroom and the environment will be organized in order to promote learning, collaboration, motivation and allow all children to participate in learning activities (Tomlinson, 2001, 2014; Tomlinson \& Allan, 2000). Based on the assessment of children's readiness, interests, learning profile, needs and other individual characteristics, teachers can differentiate the "content" in multiple ways by using: concept-based teaching; a variety of resources, appropriate and accessible materials (e.g. use of manipulatives, tactile materials, videos, audio resources, different texts, etc) and generally a range of materials and systems in order to provide and enhance access to the content (Tomlinson, 2001). "Process" can be differentiated through a range of organizational/management and instructional strategies: focusing on essential skills, information and knowledge; providing tiered lessons and activities, choices, different options and materials; hands-on activities; creating interest centers and learning centers; providing time so that every student can complete a task; using flexible grouping; providing choices and opportunities for working in small groups or working and studying independently; support by other students or teachers according to the needs of each child, etc. (Tomlinson, 2001; Tomlinson \& Allan, 2000). Differentiating "product" also includes a range of ways, options, choices and activities, through which children can demonstrate, rethink, use, apply or extend what they have learned with regards to information, knowledge understanding and skills. Based on criteria that take into consideration the diversity among children as learners, such examples are choices for working in teams or independently, creative activities with various materials and resources, oral presentations, different difficulty level of the assignments, etc (Tomlinson, 2001, 2014; Tomlinson \& Allan, 2000). Finally, the "learning environment" does not only refer to practical arrangements, but also to principles for an "effective learning community" (Tomlinson, 2001, p.21), where all children feel welcome, safe and have equal opportunities for personal achievement, growth and success (Tomlinson, 2001).

Universal Design for Learning (UDL) derives from the theoretical framework and approach of Universal Design (Pisha \& Coyne, 2001) in combination with scientific evidence regarding learning and how humans learn (CAST, 2018; Riviou, Kouroupetroglou \& Oikonomidis, 2015). Universal Design does not focus particularly on persons with disabilities but concerns all persons. It means designing from the beginning environments, spaces, buildings and products that are usable, safe and friendly to the greatest possible extent for all people taking into account their diverse needs rather than assuming an "average" user (ECA, 2003; Mace, 1988; Mace, Hardie \& Place, 1996). In education UDL stresses the importance of "the 'why', the 'what' and the 'how' of learning", which, in turn, means the provision of multiple means of engagement, representation, expression and action (CAST, 2018). In this framework the design of teaching practices, 
activities and learning programs takes from the beginning into account the diversity of learners. It also suggests a wide range of methods, materials and tools in order to respond to this diversity and provide to all children/learners opportunities for meaningful learning experiences and engagement in the learning process (CAST, 2018; Nikolaraizi, 2013; Riviou, Kouroupetroglou \& Oikonomidis, 2015). The empowerment of learners, the encouragement of collaboration, the connection with meaningful experiences or/and prior experiences and knowledge, the differentiating of the activities' difficulty level, the creation of a safe learning space, the use of multiple, alternative and accessible ways and media for information perception, the physical action, the use of different strategies and different ways as well as modalities to express what has been achieved or learned, etc., are among the suggestions and practices of UDL (CAST, 2018).

Based on the above, it becomes apparent that both theoretical models and frameworks (DI and UDL) are recommended also for STE(A)M education in order to make learning process and activities beneficial for all children including those with disabilities (Basham \& Marino, 2013; Butera et al., 2016; Zayyad, 2019). The common components of DI and UDL may be used and incorporated at different levels and in a complementary way. In formal educational settings these levels may begin "with universal design for learning principles for all, move to differentiation to maximize individual children's active participation and learning within the learning activities, and finish with individualization for addressing unique child goals and learning targets" (Horn, Palmer, Butera \& Lieber, 2016 as cited in Butera et al., 2016:153).

Although the aforementioned principles of DI and UDL concern formal education, in the field of nonformal learning environments (e.g. museums), these principles are considered as the most appropriate in order to respond to the diverse needs and characteristics of different persons as well as to the heterogeneity of persons with disabilities (Argyropoulos \& Kanari, 2019; Fletcher, 2013; Nikolaraizi, Kanari \& Marschark, 2020; Rappolt-Schlichtmann \& Daley, 2013; Shepherd, 2009). As Shepherd (2009) asserts, museum professionals can learn and benefit from the principles of DI in order to design inclusive and meaningful learning experiences for children with diverse needs and characteristics. Similarly, Rappolt-Schlichtmann and Daley (2013, p. 308) underline that UDL "has the potential to substantially improve the design" of learning environments, as for example museums, in order to support and improve the learning and social experiences of persons with disabilities. The aforementioned scientific and educational fields and theoretical approaches constitute the basis for a case study of a museum educational program for children with disabilities which was designed and implemented in a technological museum following the STEAM approach.

\section{The case of an educational program based on STEAM approach in the Rooftile and Brickworks Museum N. \& S. Tsalapatas for children with disabilities}

The following sections describe the case of an educational program based on the STEAM approach for a school group of children with disabilities which took place in a thematic 
technological museum for the industrial heritage in Greece. More analytically, the following sections present $a$. the place and the framework of the collaboration, $b$. the design and implementation stages, the participants, the structure and the content of the educational program, and c. the evaluation of the program.

\subsection{The place and the framework of the collaboration}

The educational program entitled "Making mosaics with bricks and colors" was implemented with a school group of children with disabilities in the Rooftile and Brickworks Museum N. \& S. Tsalapatas. The museum is one of the nine thematic technological museums which form the museum network of the Piraeus Bank Group Cultural Foundation (PIOP) in Greece (Louvi, 2007)v. The aims of the PIOP museum network include: the protection of the Greek cultural heritage with an emphasis on the traditional, artisanal and industrial technology; the highlighting of the relevant technological, social, economical, historical and artistic dimensions of each thematic museum in a local or broader level; the development of collaborations with various institutions, professionals, etc. (Louvi, 2015; Mouliou, 2015). The Rooftile and Brickworks Museum N. \& S. Tsalapatas is an old factory which has been transformed into a museum. In other words, as Louvi (2007, p. 44) states "it is a museum of itself" (Fig. 1). In this emblematic and imposing space visitors can see the mechanical equipment of the old factory - including the Hoffmann kiln, the stages of the production of different types of bricks and tiles - and also be informed about the life of its workers. The Rooftile and Brickworks Museum N. \& S. Tsalapatas - and all the museums of PIOP organize and offer a variety of educational programs for school groups ${ }^{\mathrm{vi}}$.

\footnotetext{
vThe nine museums of the PIOP museum network are located in different Greek provincial areas and are the following: the Rooftile and Brickworks Museum N. \& S. Tsalapatas (Volos), the Silk Museum (Soufli), the Silversmithing Museum (Ioannina), the Museum of Industrial Olive-Oil Production (Lesvos), the Chios Mastic Museum, the Museum of Marble Crafts (Tinos), the Open-Air Water Power Museum (Dimitsana), the Museum of the Olive and Greek Olive Oil (Sparta) and the Environment Museum of Stymphalia (Korinthia). For more information about the aforementioned museums, their collections and activities see the official website of PIOP https://www.piop.gr/en/diktuo-mouseiwn.aspx (Accessed on June 16, 2020). vi See also the official website of the museum: https://www.piop.gr/en/diktuo-mouseiwn/MouseioPlinthokeramopoieias-Tsalapata/to-mouseio.aspx (Accessed on June 16, 2020).
} 


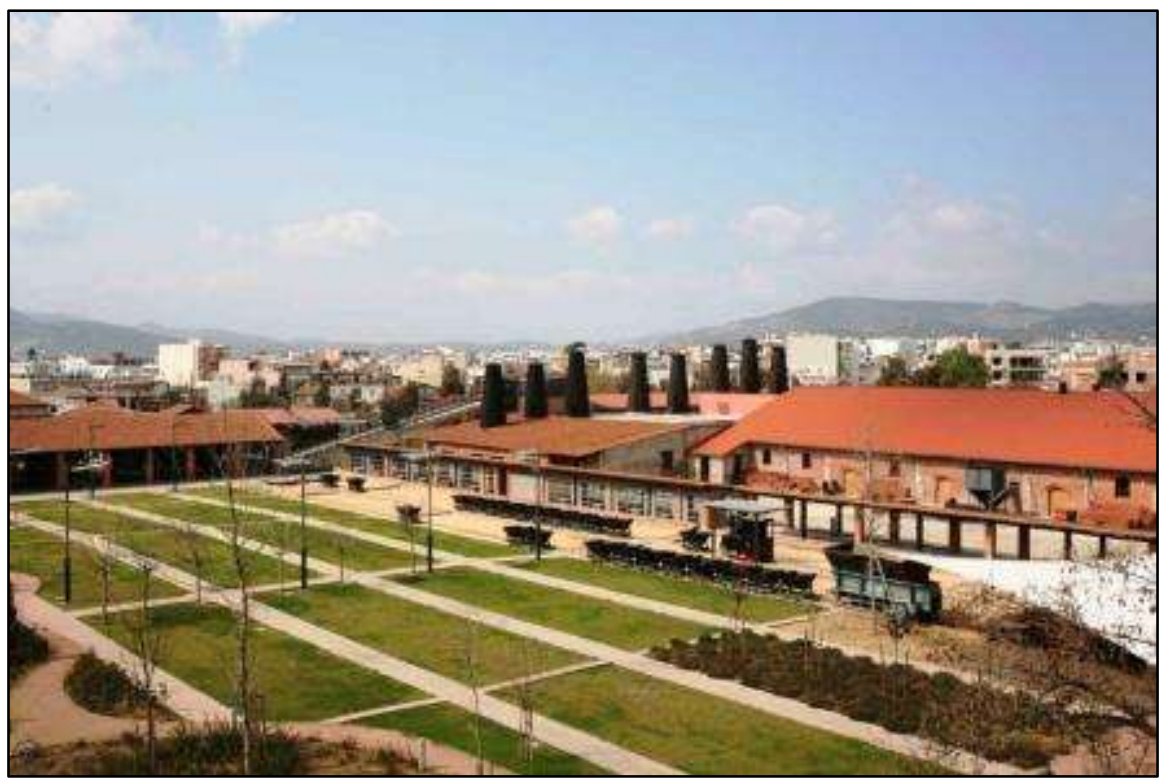

Figure 1: External view of the Rooftile and Brickworks Museum N. \& S. Tsalapatas (Photo: Ioannis Kizis/Photo Files PIOPvii)

The educational program "Making mosaics with bricks and colors" took place on the occasion of the International Museum Day 2019. The theme of the International Museum Day 2019 was related to the tradition, as clearly indicated in its title "Museums as Cultural Hubs: The future of tradition" (https://icom.museum/en/news/imd2019museums-as-cultural-hubs-the-future-of-tradition/). The Hellenic National Committee of the International Council of Museums (ICOM) has selected the PIOP Foundation as the honored institution in Greece for its unique contribution to the protection and promotion of traditional and industrial technology as well as for its wide educational and social activities (http://icom-greece.mini.icom.museum/news/).

The aforementioned educational program was part of many other activities that took place within PIOP museums in the frame of the International Museum Day 2019. The design of the educational program was the result of the collaboration between professionals of different specialties, i.e. between a visual artist and art educator with specialty in STEAM education and a special education teacher and museum educator. The contribution of the staff of the Rooftile and Brickworks Museum N. \& S. Tsalapatas was also very important for the provision of relevant information and materials as well as for the general support during the implementation of the program.

\subsection{Design and implementation stages of the program}

The educational program was designed and implemented into the following stages: $a$. preliminary actions, b. implementation of the educational program, and c. evaluation of the educational program.

vii Retrieved 15 May, 2020 from https://www.archaiologia.gr 


\subsubsection{Preliminary actions}

According to Nikonanou (2010) the design of an educational program in a museum should take into account the qualitative characteristics of the museums as nonformal learning environments, the target group, the space of the museum and the social dimension of the educational activities and the museum experience.

Thus, the authors first communicated with the school teachers of the Special School in order to discuss about the profile, the characteristics and the needs of the participating children with disabilities. Another action was a visit at the Rooftile and Brickworks Museum N. \& S. Tsalapatas in order to identify aspects of the route within the museum in relation to specific exhibits, interpretative means and other available facilitations. As mentioned above (see 3.1), the Rooftile and Brickworks Museum N. \& S. Tsalapatas is an old factory which has been transformed into a museum. The space and the exhibits of the museum were very important axes for the design of the educational program based on the STEAM approach. Furthermore, the museum has animated and scale models, audiovisual material as well as a room with miniatures of the factory machines for the implementation of educational programs and activities for children (https://www.piop.gr/en/diktuo-mouseiwn/Mouseio-PlinthokeramopoieiasTsalapata/to-mouseio.aspx).

At this stage, another preliminary action was the preparation of the materials for the art activities of the educational program. More precisely, this included coloring the miniature bricks, preparing the cardboards and designing the visual patterns which would be given to participants for creative exploitation.

The design and the objectives of the educational program were based on: a. the characteristics and needs of the schoolchildren with disabilities, $b$. aspects of the STEAM education and c. the site-specific characteristics of the Rooftile and Brickworks Museum N. \& S. Tsalapatas. Following this threefold approach, the aims of the educational program were for students to: a. experientially recognize changes in matter (e.g. clay soil, clay and bricks), b. to identify machines for the production of bricks and tiles, c. to describe specific characteristics of the bricks (e.g. shape, size, etc), d. to create their own artworks using miniatures of bricks, and e. to communicate and collaborate with each other and with adults.

The design of the educational program was based on the principles of DI and UDL (see section 2.4). Among the main principles that were taken into consideration were: the focus on essential knowledge and skills based on children's characteristics; the connection with prior experiences and daily life experiences; the use of multiple and alternative ways for the representation of information such as authentic objects, materials and models; the promotion of the active and multisensory engagement of the children; the hands-on activities; the use of visual patterns; the provision of choices for creative activities in groups or independently; choices to create their own end product; the use of simple and understandable vocabulary; the creation of a safe, welcoming and supportive learning environment; the varied level of children's support during the activities, etc. It is also important to mention the specific facilitations available in the Rooftile and 
Brickworks Museum N. \& S. Tsalapatas. The animated model for the construction process of bricks and tiles, the availability of authentic bricks and materials (e.g. bricks, clay soil) as well as the miniatures of factory machines (Fig. 2 and 3) provided unique opportunities for the design and the implementation of the program.
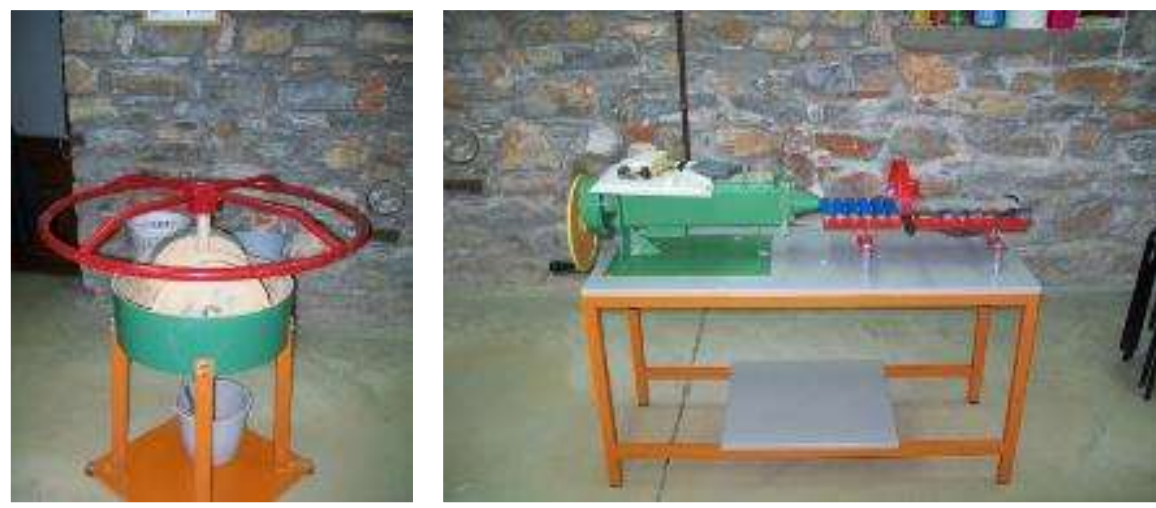

Figure 2 and 3: Miniatures of the factory machines for educational activities in the Rooftile and Brickworks Museum N. \& S. Tsalapatas

(Source: Authors' file photo)

\subsubsection{Implementation of the educational program - Participants}

The educational program took place during the school hours as part of the school field trips. The duration of the program was approximately two hours. Seven children with various disabilities - intellectual disabilities, autism spectrum disorders and deaf children - from a local Special School attended the educational program. Five Special Education teachers (SETs) were accompanying the children. SETs' support was very important including the interpretation in Greek Sign Language by a SET. The educational program was implemented by two professionals: one of them in art and STEAM education and the other in Special Education and Museum Education. Furthermore, two members of the museum staff were following the process of the educational program.

\subsubsection{The structure and the content of the educational program}

The educational program was structured in three stages: a. outdoor acquaintance activities at the museum yard, b. short guided tour inside the museum with demonstration of the factory's machinery, and c. activities in the educational program's room. At the first stage children were welcomed in the museum yard and introductory acquaintance activities took place in order to create a friendly, safe and playful atmosphere. Furthermore, children got familiar with the old factory machinery exhibited outdoors. There was a discussion about the use and function of the machines as well as about other outdoor museum settings. At the second stage of the program there was a short guided tour inside the museum with demonstration of the animated model and the process of the bricks production as well as the exhibits where the bricks were stored. Particular attention was paid to communication with simple and understandable vocabulary and to the prior knowledge of children (e.g. bricks and houses, shape of the bricks, etc). With simple questions children were encouraged to observe, to communicate 
their own ideas and to show specific elements (e.g. how the machinery moved, how the workers were carrying the bricks, etc). The third stage of the program, which was the longer one, took place in the museum's room of educational activities. There the children discovered the modus operandi of the clay and brick machines displayed in the room of educational activities and they had the opportunity to see and explore the miniatures of the factory machines (see above Fig. 2 and Fig. 3). They also experienced clay and bricks with multiple senses and ways: vision, touch, smell of clay and bricks. They had the opportunity to touch and feel the properties of clay soil, to observe, to touch, to name shapes, to measure the dimensions of an authentic regular-sized brick, ask questions, etc. (see Fig. 4, 5 and 6). A great emphasis was also placed on the encouragement of children's active participation as well as on the interaction among them and with the adults (with their teachers and the persons who conducted the program).
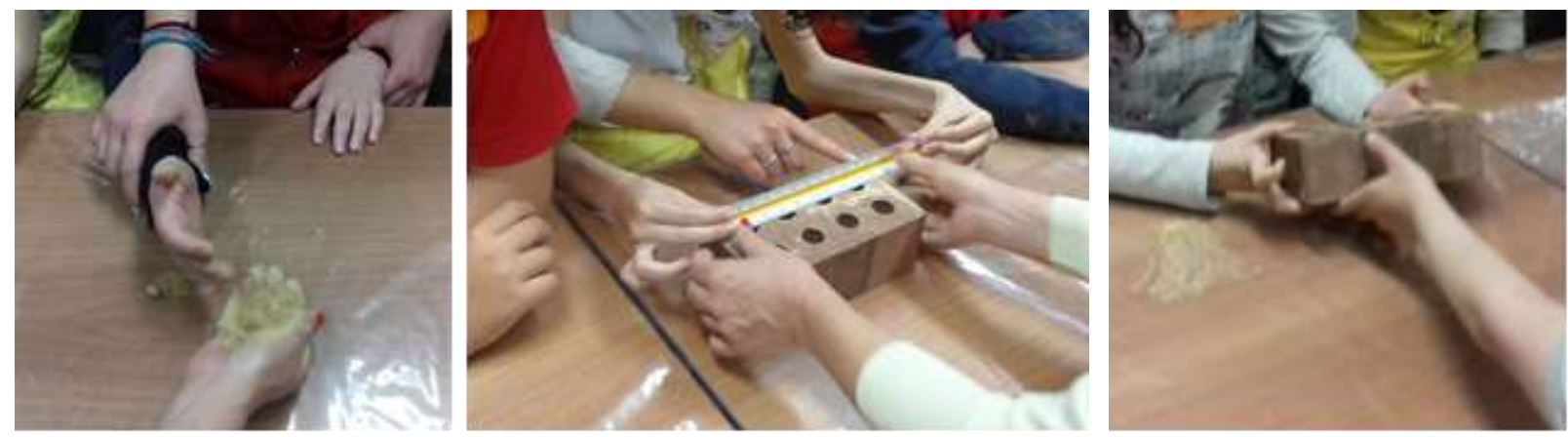

Figures 4, 5 and 6: Exploring the properties of the clay soil.

Observing, touching, naming and measuring an authentic regular-sized brick

(Source: Authors' file photos)

Afterwards, children created their own artworks with colored and clay miniature bricks. Children also were given pre-designed patterns and they had the choice either to use and follow the patterns or to create a mosaic by themselves. They also had the choice to create a mosaic in collaboration with their peers or independently. Clay is a traditional material par excellence which is very often used in education. However, in the frame of this educational program, clay miniature bricks were used in order to form mosaics and radically embrace the contemporary STEAM approach in the Rooftile and Brickworks Museum N. \& S. Tsalapatas settings. As showed in the following sections, children came up with interesting aesthetic results.

\subsubsection{Evaluation of the educational program}

The evaluation of the educational program was based on qualitative data. More precisely, the qualitative data were obtained via a. field notes taken by the authors during the art activities, b. evaluation sheets filled in by the SETs who accompanied the children, and c. evaluation sheets filled in by the members of the museum who were following the program. 
More analytically, since the authors were also supporting the children during the art activities, they were writing keywords of phrases and right after the implementation of the program they wrote down the field notes. The field notes were based on an observational protocol (Isari \& Pourkos, 2015), focused on the choices of the children (use of patterns or not), the ways in which children used the materials, the interaction within the group of children with disabilities and the level of support by their teachers .The evaluation sheets for SETs included, in total, twenty open-ended questions structured in four axes: a. prior experiences with their students in the Rooftile and Brickworks Museum N. \& S. Tsalapatas, b. their views about the specific educational program, c. their views about the response and the learning outcomes for their students, and $d$. the use of arts and their interest about the STEAM approach. Similarly, the evaluation sheets for the museum staff included, in total, twenty open-ended questions and they were structured in four axes: a. implementation of educational programs with children with disabilities, b. their prior knowledge and experience of educational programs designed with the STEAM approach, $\mathrm{c}$. their views regarding the specific educational program, and $\mathrm{d}$. their interest in the STEAM approach and museum educational programs. The total number of the gathered evaluation sheets was 7 ( 5 from the SETs and 2 from the museum staff). The analysis of the data from the evaluation sheets was held with content analysis (Miles \& Huberman, 1994). The following section presents some of the main results of the evaluation of the program.

\section{Evaluation results of the educational program}

Based on the field notes it was observed that not all children chose to use the provided pre-designed patterns and not all children used the patterns and materials in the same way. There were children that from the very beginning of the art activities stated clearly that they wanted to create their own artworks ("I want to do something else"). For example, a child did not at all follow the pre-designed pattern neither the basic concept of the workshop to make mosaics. From the very beginning of the making process he announced clearly his decision to make his own drawing of a house. Figures 7 and 8 show his $3 \mathrm{D}$ construction of colorful miniature bricks on top of a 2D drawing of a house. The necessity to use a 2D drawing and then develop a rectangular 3D brick wall reminds the work of the architect using a ground plan to build their scale model. Even though the 2D drawing is a front view of a house and not a ground plan and despite the fact that 2D drawing does not really match the 3D drawing, the coexistence of $2 \mathrm{D}$ drawing and $3 \mathrm{D}$ construction shows the 2D and 3D interpretation of the house in child's perception. 

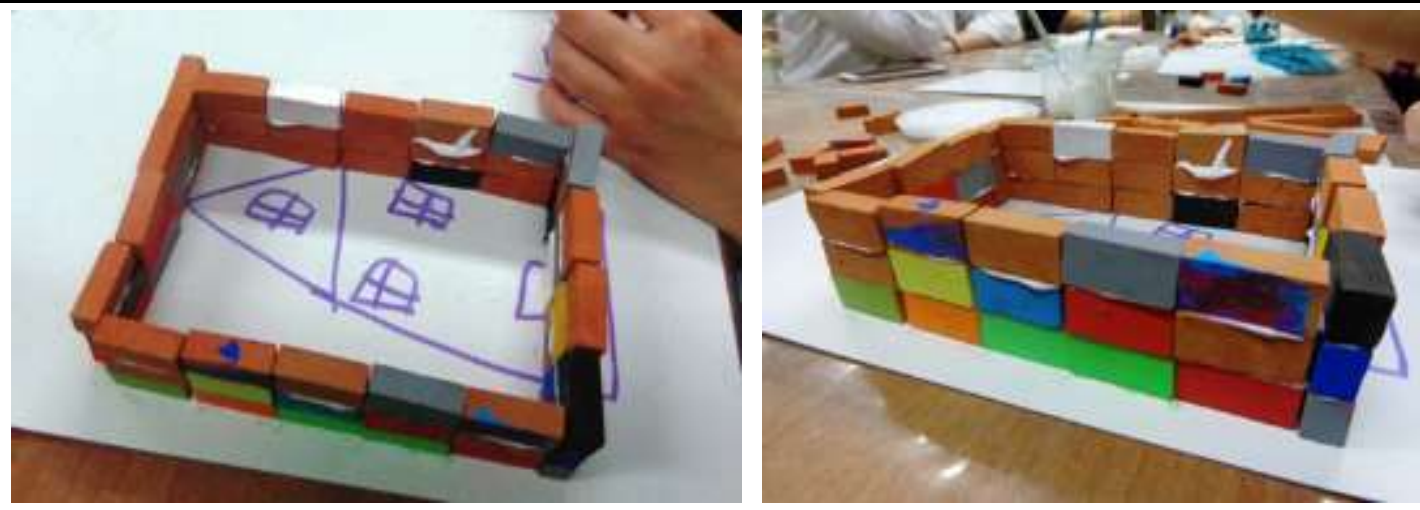

Figure 7 and 8: Student's artwork with 2D drawing and 3D construction

(Source: Authors' file photos)

In the case of children who chose to use the pre-designed patterns, it was observed that they did not necessarily follow the structure of the initial drawing, i.e. they did not match the miniature bricks with the positions indicated in the drawing. What they did, instead, was that they placed the miniature bricks in other positions, not randomly, but by following another structural rule of their own. For example the choice of a student (Fig. 9 and 10) to put the building blocks with the biggest surfaces facing aside (instead of facing up and down) and out of the contour of the ladder drawing was an unexpected structural choice. However, the fact that the student put the miniature bricks in a row following the outer contour proves that she was following a rule other than the original one indicated in the drawing. Another interesting characteristic of her approach was her choice to put miniature bricks -this time with the biggest surfaces facing up and downwithin the space between the stairs of the ladder and not within the space of each stair. In both choices she placed the blocks in the negative space of the drawing. Moreover, not only did she put the blocks in the space between the stairs of the ladder, but she also chose to do so by using blocks of different colors. All these choices make her final construction very interesting. This is because the different placement of the blocks (face aside and face up-down) makes the third dimension more obvious, since the miniature bricks appear in different heights on the drawing surface. As the eye moves on her final construction, it captures an interesting spatial play which is achieved with the different heights, as well as with the different sizes of the face-up surfaces of the miniature bricks. The whole composition becomes even more interesting with the use of different colors for the stairs which facilitates -with the aid of the color change- the movement of the eye around the whole composition. In this sense, her final construction does give the sense of steps, even if it does not follow the pre-designed pattern or -more accurately- even if it does not follow what was originally in the mind of the person who made the predesigned pattern. 


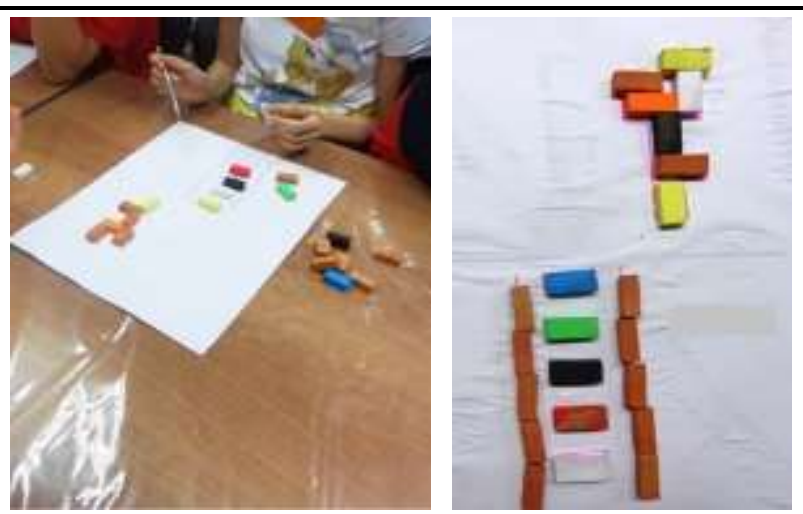

Figure 9 and 10: Student's artwork with stairs

(Source: Authors' file photos)

There were also children who followed the pattern drawings (see Fig. 11, 12 and 13) either with raw miniature bricks or with colorful miniature bricks. It is important to notice that color was not used in all mosaic compositions. Instead, some children chose to make their mosaics only with raw clay bricks (see Fig.13). This probably indicates that color was not essential for all compositions. The role of the color was aesthetic, but also functional since it made certain forms distinguishable, as for example in the case of the trunk and the leaves of the tree (see Fig.11).
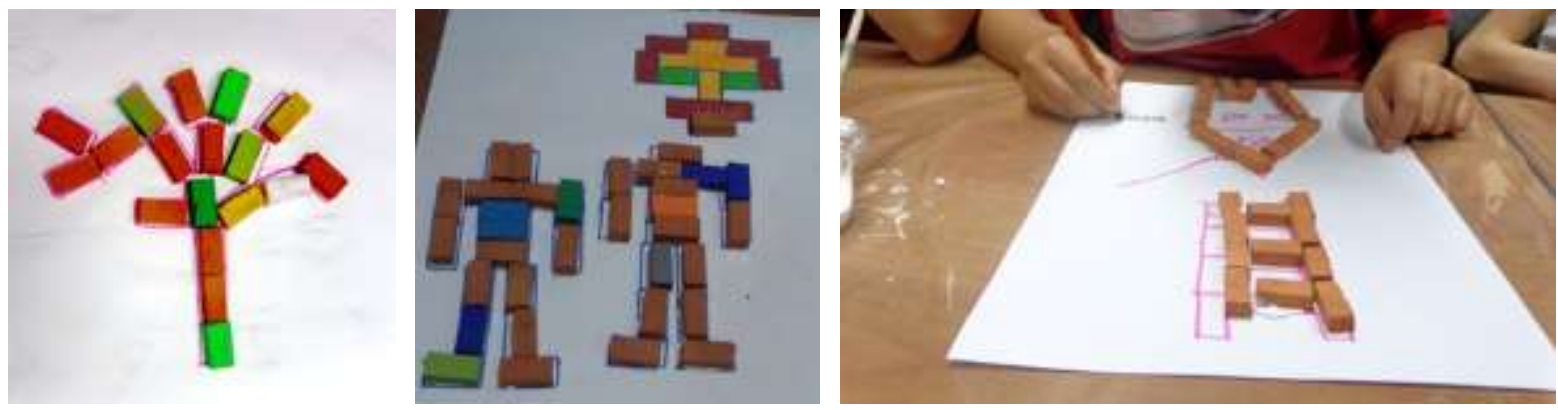

Figure 11, 12 and 13: Students' different creative approaches and artworks

At the end children came up with interesting aesthetic results through different approaches. As indicated above, children made their own choices with regards to the exploitation of the initial patterns, the colors and the 2D and/or 3D structure of their compositions. Regarding the level of support, children obviously needed varied levels of support during the activities without, however, putting limits to children's choices, initiatives and creativity (Butera et al., 2016). As mentioned above, children were encouraged to interact with their peers and the adults. Indeed, children wanted to share their choices and they were encouraged to show their final artworks. All the artworks were given to children and they were exhibited in the school.

Based on the evaluation sheets of SETs some of the main results were that all participants had visited in the past the Rooftile and Brickworks Museum N. \& S. Tsalapatas with their students in order to attend educational programs with different topics. However, it was the first time that they were attending an educational program based on the STEAM approach. Furthermore, none of the participants had knowledge 
about STEAM education, but all of them expressed their interest to learn more about STEAM and how they can take advantage of this approach for the benefit of their students. Regarding their views about the educational program "Making mosaics with bricks and colors", all the participants found the educational program interesting for the following reasons (see Table 1):

Table 1: Special Education teachers' (SETs) views about the educational program "Making mosaics with bricks and colors"

\begin{tabular}{|c|c|}
\hline Categories & Subcategories \\
\hline $\begin{array}{l}\text { Type of activities of } \\
\text { the educational program }\end{array}$ & $\begin{array}{l}\text { Multisensory activities } \\
\text { Understandable activities } \\
\text { Adjusted activities for students with disabilities } \\
\text { Combination of materials [bricks] with art activities } \\
\text { Experiential learning } \\
\text { Individual and group activities }\end{array}$ \\
\hline $\begin{array}{l}\text { Structure of } \\
\text { the educational program }\end{array}$ & $\begin{array}{l}\text { Cohesion } \\
\text { Appropriate sequence of activities }\end{array}$ \\
\hline $\begin{array}{l}\text { Implementation of } \\
\text { the educational program }\end{array}$ & $\begin{array}{l}\text { Appropriate preparation of the professionals } \\
\text { Supportive environment } \\
\text { Communication } \\
\text { Encouragement }\end{array}$ \\
\hline $\begin{array}{l}\text { Learning outcomes and } \\
\text { benefits for children }\end{array}$ & $\begin{array}{l}\text { Communication skills } \\
\text { Collaboration skills } \\
\text { Social interaction } \\
\text { Fine motor skills } \\
\text { Language skills } \\
\text { Observation } \\
\text { Motivation for participation } \\
\text { Active participation } \\
\text { Enjoyment, enthusiasm } \\
\text { Self -esteem } \\
\text { Creativity } \\
\text { Socialization } \\
\text { Expanding children's experiences } \\
\text { Knowledge }\end{array}$ \\
\hline
\end{tabular}

As seen in the above Table (Table 1), SETs expressed positive views about various aspects of the educational program as well as for the learning outcomes and the benefits for the children. They commented the interesting approach with the combination of building materials (e.g. bricks) with art activities, the multisensory and experiential learning, the appropriate adjustment of the activities "for children from a Special School" that provided opportunities to children to actively participate, communicate, collaborate and express themselves. They also mentioned the cohesive and appropriate transition from one activity to the other as well as the friendly, encouraging and supportive learning 
environment that allowed children to make their own choices, create their own artworks and feel proud.

Furthermore, SETs mentioned a range of learning outcomes and benefits for children including communication and social skills, language skills, fine motor skills and knowledge (e.g. shapes, numeracy, vocabulary, etc). They also stressed the motivation and active participation of all children according to their different needs and characteristics, the enjoyment and the importance of new experiences as well as the socialization in out-of-school environments such as museums. Some indicated comments are the following:

"It was a really new approach to combine materials of a factory with art. Children were excited" (SET1) viii.

"The activities motivated children and all of them participated actively in their own ways" (SET5).

"Children had the opportunity to observe, communicate and cultivate fine motor skills" (SET3).

"The program had a good structure with activities adjusted to the needs of our students" (SET1).

"It is very important to provide new experiences to our students in different spaces and not only in school. They learn to communicate and collaborate. I believe that all children can be creative if they have appropriate opportunities..." (SET2).

"My student was so proud for his artwork!" (SET2).

"Children felt free to express themselves ... it was very interesting to combine mathematic concepts with arts, shapes, colors in a factory...it was a really remarkable experience." (SET4).

Regarding museum staff, based on their evaluation sheets, it is worth mentioning that the Rooftile and Brickworks Museum N. \& S. Tsalapatas design and offer educational programs for school groups of children with disabilities with various themes (e.g. industrial heritage, intangible cultural heritage, etc). These educational programs include art activities (e.g. drawing, theatre-pedagogic techniques, etc) with the aims of acquiring knowledge, developing various skills (e.g. fine motor skills, collaboration and communication skills), fostering creativity and social inclusion. Both members of the museum staff who attended the educational program and filled in the evaluations sheets

viii Code "SET1, SET2..." refers to the Special Education Teachers who participated in the evaluation of the educational program. 
mentioned that they have some general knowledge about the STEAM approach mainly from internet resources. They characterized the educational program as an "excellent", "important" and "very interesting" approach:

"It was very interesting to realize that you can "see" the same materials from different perspectives and use the information in multiple ways...children/visitors can acquire a complete experience in a very creative way" (MS1) ${ }^{\mathrm{ix}}$.

"It was an excellent program...STEAM approach is very important since it is a more complete approach which can be used with all target audiences" (MS2).

Museum staff also mentioned that they would like to learn more about the STEAM approach and especially in relation to the thematic museums of PIOP museums network:

"We have seen many programs based on the STEM approach. However, the introduction of arts in this approach is very important. After all, we are a museum network with Technology and Science, and we need more arts and mathematics!" (MS2).

Furthermore, in the case of school groups with children with disabilities, both museum staff members stressed the importance of the collaboration with Special Education teachers.

\section{Discussion and suggestions}

The theoretical basis of the present case study of a museum educational program is the STEAM approach for children with disabilities. Further and wider than STEAM, the cross-disciplinary approach implemented in the educational program "Making mosaics with bricks and colors" involves the conjunction and the synergy of STEAM Education, Museum Education and Special Education. This creative synergy reveals many convergence points. STEAM Education is a learner- centered approach (Zayyad, 2019) which is in line with the contemporary educational theories, theoretical frameworks and practices that place emphasis to the characteristics of learners and how people learn, namely Differentiated Instruction and Universal Design for Learning (CAST, 2018; Tomlinson, 2001). Similarly, Museum Education and learning in the museum is oriented to an audience/visitor/user -centered approach (Black, 2005, 2012) that aims to provide meaningful learning and social experiences to all people according their different characteristics, needs, interests, etc. The theoretical frameworks of DI and UDL are in the heart of the discussion in formal education (CAST, 2018; Tomlinson, 2001), in nonformal learning environments as for example museums (Argyropoulos \& Kanari, 2019; Nikolaraizi, Kanari \& Marschark, 2020; Rappolt-Schlichtmann \& Daley, 2013; Shepherd,

ix Code "MS1, MS2" refers to the members of the museum staff who participated in the evaluation of the educational program. 
2009) as well as in STEAM Education (Butera et al., 2016; Zayyad, 2019) providing a range of methods and tools for the enhancement of access and participation in the learning process. Furthermore, learning is a lifetime process that occurs in different contexts and settings (Norqvist \& Leffler, 2017) and aims to the personal development of each person and to the acquisition of knowledge and skills - including $21^{\text {st }}$ century skills. Knowledge and education are recognized as common goods (UNESCO, 2015) and both Special Education and Museum Education -regardless of their differences as formal and nonformal/informal settings - share common goals, as for example the inclusion and the equal access and participation to education, knowledge and cultural and social life (Bounia, 2015; Argyropoulos \& Kanari, 2019; Kanari, 2015). Museums and the qualitative characteristics of learning in the museum (Grant \& Patterson, 2016; Hooper-Greenhill, 2007; Nikonanou, 2010; Vartiainen \& Enkenberg, 2013) provide unique opportunities for STEAM based educational programs and activities. Furthermore, this threefold approach shares common aims in relation to a range of learning outcomes (Argyropoulos \& Kanari, 2019; Hooper-Greenhill, 2007; Hwang \& Taylor, 2016; Maslyk, 2016; Zayyad, 2019).

Towards this direction it is considered necessary to develop collaborations, crossdisciplinary approaches, partnerships and networks in order to provide student-centered activities and equal opportunities to all children and young people including those with disabilities (Argyropoulos \& Kanari, 2019; Falk et al. 2016; Staus, et al. 2020; Vartiainen \& Enkenberg, 2013). The following diagram (Table 2), unveils the convergence points among STEAM Education, Museum Education and Special Education as well as the need for interdisciplinary collaborations, partnerships and networks.

Table 2: STEAM Education, Museum Education, Special Education: convergence points, contexts and collaborations

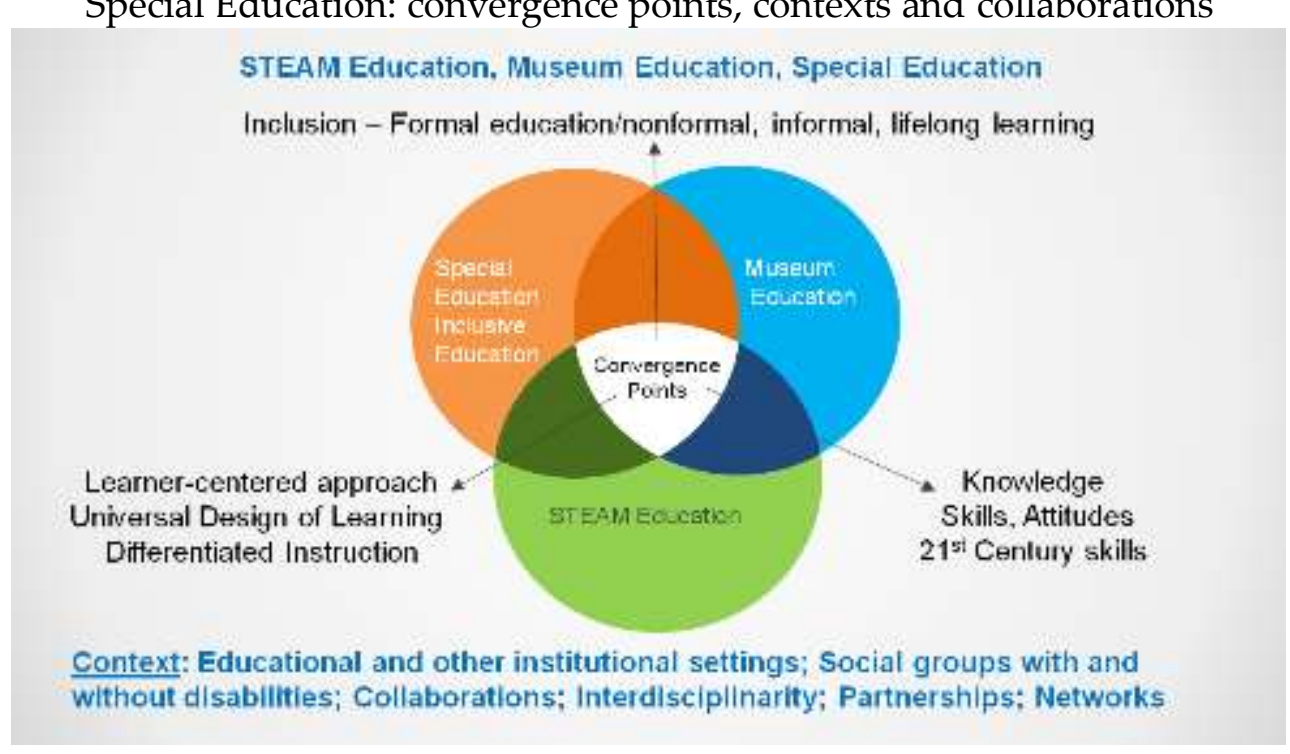

The cross-disciplinary approach, the collaboration with Special Education teachers and the museum staff were essential in the educational program "Making mosaics with bricks and colors". Team-teaching is also very important in widely cross-disciplinary initiatives (Shibley, 2006). In the case of the educational program presented in this paper, 
team-teaching was necessary in order to cover multiple aspects and perspectives in the fields of STEAM education (more precisely, in the fields of visual arts, mathematics, architecture, engineering and technology), as well as Museum Education and Special Education. Another basic characteristic of this educational program was obviously the industrial character of the museum where the educational program took place. The design and the implementation of the present educational program were inextricably related to the unique and specific collection and resources of the Rooftile and Brickworks Museum N. \& S. Tsalapatas (equipment, machinery, miniatures of the factory machines and materials). This means that it is not possible to repeat an identical educational program in another museum or other organization. However, the case of the present educational program reveals the potential dynamic of each museum to take advantage of its own unique resources, expand and implement context-specific activities and programs based on STEAM Education and develop various collaborations.

In the case of the educational program presented in this paper, the thematic character of the Rooftile and Brickworks Museum N. \& S. Tsalapatas calls for consideration of the technology and engineering aspects of the space, the machines and other industrial exhibits. The geometry of the bricks and their use as building units or tiles in children's constructions and mosaics prompted the use of mathematics. Children's constructions transform the bricks into figurative or abstract images which link their creations with the arts. The clay bricks, which a priori have a certain function as building units mainly used for three-dimensional constructions, are transformed into colorful and/or structural units for making mosaics in two as well as in three dimensions. Thus, the bricks obtain an aesthetic value in their shaping colorful and/or structural forms. Whether these forms are figurative or abstract, they render the bricks a material with considerable potentiality with regards to design and art making. The initial functionality of the bricks as building units is, thus, enriched and elaborated with the aesthetic and artistic dimension which constitutes an added value with possible applications in arts, design and architecture. However, it is important to note that the description of children's artworks (see section 4), does not aim or attempt to interpret them in terms of cognitive process but to reveal that all children have their own way to express themselves creatively through arts and in relation to concepts derived from other disciplines. As stated in the present paper the STEAM embraces art forms and creatively connects them with STEM fields in a way that promotes both parts of the STEM $+\mathrm{A}=$ STEAM equation.

Another element that's worth mentioning is children's support by teachers and instructors. Butera et al. (2016, p.150) point out the significance of intentional teaching that promote a balance between children's choices, "children's initiated interactions and teachers' support and guidance". This is of particular importance for children with diverse needs and abilities and in relation with different educational and developmental domains. As described above (see section 4), during the implementation of the educational program children with various disabilities obviously needed varied levels of 
support and guidance but without setting limits to children's choices, initiatives and creativity.

Since STEAM education benefits all students including those with disabilities (Butera et al., 2016; Hwang \& Taylor, 2016; Maslyk, 2016; Zayyad, 2019) it is important to provide teachers with similar methodologies, to promote awareness about STEAM education (Allina, 2018) as well as about Museum Education. The provision of resources, time and materials, team working and the adoption of the principles of DI and UDL in order to meet the needs of all students, including those with disabilities, during the implementation of STEAM activities are also considered crucial parameters (Butera et al., 2016).

In conclusion, the possibility of carrying out context-specific activities and workshops where all or some of the above fields are creatively connected constitutes a subject for further investigation. Children with disabilities have the right for equal access and participation in education and in different learning contexts and environments in order to promote inclusion in terms of quality. Towards this direction there is a need for synergies and collaborations among different settings, sectors and professionals, the evaluation of relevant programs and the diffusion of best practices and examples for the benefit of all children including those with disabilities.

\section{Acknowledgments}

We highly acknowledge the Piraeus Bank Group Cultural Foundation (PIOP) and the staff of the Rooftile and Brickworks Museum N. \& S. Tsalapatas for their support. We also express our thankfulness to the Special Education teachers from the Special School.

\section{About the authors}

Dr. Charikleia Kanari holds two Bachelors in Special Education and in Museum Education and a PhD in Special Education, Visual Impairment and Museum Education from University of Thessaly. Her research interests include issues of access and inclusion of children with and without disabilities in formal education, nonformal and informal learning and cultural environments. She has published papers in international peerreviewed journals, conference proceedings and chapters in national and international books. She is currently a postdoctoral researcher and adjunct lecturer at the Department of Special Education of the University of Thessaly.

Dr. Anastasia Zoi Souliotou is a visual artist and holds a PhD from Paris- 8 University in Aesthetics, Sciences and Art Technologies. She has also carried out a post-doctoral research on the importance of the Arts in Science, Technology, Engineering, Arts and Mathematics (STEAM) education. Her research has been presented in national and international conferences and published in journals of art, technology and education. 


\section{References}

Aggelidis, P., \& Avraamidou, L. (2011). Inclusive education within informal learning environments. In: P. Aggelidis (Ed.), Pedagogies of inclusion (pp. 17-42). Athens: Diadrasi (in Greek).

Ambrose, T., \& Paine, C. (2018). Museum Basics. London: Routledge.

Allina, B. (2018). The development of STEAM educational policy to promote student creativity and social empowerment. Arts Education Policy Review, 119 (2), 77-87, doi:10.1080/10632913.2017.1296392

Argyropoulos, V., \& Kanari, Ch. (2019). The role of non-formal learning environments in education and socialization of children with visual disability: the case of museums. In: S. Halder \& V. Argyropoulos (Eds), Inclusion, equity and access for individuals with disabilities (pp. 125-151). Singapore: Palgrave Macmillan.

Argyropoulos, V., Nikolaraizi, M., Kanari, Ch., Chamonikolaou, S., Plati, M., Markou, E., \& Leotsakou, B十. (2017). Bridging theory and practice in developing inclusive practices in museum: The Greek case. Proceedings of the 9th ICEVI European Conference "Empowered by dialogue". Bruges, 2 - 7 July 2017 (pp. 40-41). Bruges, Belgium.

Argyropoulos, V., Nikolaraizi, M., Chamonikolaou, S., Kanari, Ch. (2016). Museums and people with visual disability: An exploration and implementation through an ERASMUS+ Project. Proceedings of EDULEARN2016 Conference, 4 - 6 July, 2016 (pp. 4509-4516). Barcelona, Spain.

Bati, K., Yetişir, M. I., Çalişkan, I., G., Güneş G., \& Gül Saçan, E. (2018). Teaching the concept of time: A steam-based program on computational thinking in science education. Cogent Education, 5(1), 1507306, doi:10.1080/2331186X.2018.1507306

Bazler, J., \& Sickle, M. Van (Eds.) (2017). Cases on STEAM education in practice. USA: IGI Global.

Bell, S. (2010). Project-Based Learning for the 21 $1^{\text {st }}$ century: Skills for the future. The Clearing House, 83 (2), 39-43, doi:10.1080/00098650903505415

Basham, J. D., \& Marino, M. T. (2013). Understanding STEM education and supporting students through Universal Design for Learning. TEACHING Exceptional Children, 45(4), 8-15, doi:10.1177/004005991304500401

Bellanca, J., \& Brant, R. (Eds) (2010). 21 st century skills: Rethinking how students learn. Bloomington: Solution Tree Press.

Black, G. (2012). Transforming museum in the twenty first century. London: Routledge.

Black, G. (2005). The engaging museum. Developing museums for visitor involvement. London - N.Y.: Routledge.

Bounia, A. (2015). Reaching different communities: Actions of social inclusion, intercultural education and enhancing accessibility for persons with disabilities. In: N. Nikonanou (Ed.), Museum learning and experience in $21^{\text {st }}$ century (pp. 127-147), [ebook]. Athens: Hellenic Academic Libraries Link (in Greek). Retrieved April 20, 2020 from https://repository.kallipos.gr/handle/11419/717 
EDUCATION OF CHILDREN WITH DISABILITIES IN NONFORMAL LEARNING ENVIRONMENTS: A CROSS-DISCIPLINARY APPROACH OF STEAM EDUCATION IN A TECHNOLOGICAL MUSEUM IN GREECE

Butera G., Horn, E. M., Palmer, S. B., Friesen, A., \& Lieber, J. (2016).Understanding Science, Technology, Engineering, Arts, and Mathematics (STEAM) within early childhood Special Education. In: B. Reichow, B. Boyd, E. Barton \& S. Odom (Eds), Handbook of early childhood Special Education (pp. 143-161). Switzerland: Springer International Publishing.

CAST (2018). Universal Design for Learning Guidelines version 2.2. Retrieved April 20, 2020 from http://udlguidelines.cast.org

Chang, E. J., \& Lee, B. Y. (2019). Investigating STEAM Education both in the USA and South Korea. In: G. Coutts \& T.T. de Eça (Eds.) Learning through art: Lessons for the 21st century? (pp. 39-52). São Salvador: INSEA Publications, doi:10.24981/978LTA2018. $\quad$ Retrieved $20 \quad$ June, 2020 from https://www.insea.org/docs/inseapublications/Learning-through-art-lessons-forthe-21-century.pdf

Conner, L. (2016, November, 10). Broadening participation in science by integrating Art with STEM. Center for Advancement of Informal Science Education (CAISE). Retrieved June 23, 2020 from https://www.informalscience.org/newsviews/broadening-participation-science-integrating-art-stem

Coxall, H. (2006). Open minds: Inclusive practices. In H. H. Genoways (Ed.), Museum philosophy for the twenty-first century (pp. 139-149). United States: Altamira Press.

DCMS (2000). Centres for social change: Museums, galleries and archives for all. Policy guidance on social inclusion for DCMS funded and local authority museums, galleries and archives in England. London: Department of Culture, Media and Sport, Retrieved April 20, 2020

from

https://webarchive.nationalarchives.gov.uk/20100113222743/http:/www.cep.cult ure.gov.uk/images/publications/centers social change.pdf

Dodd, J., \& Sandell, R. (Eds.) (2001). Including museums. Perspectives on museums, galleries and social inclusion. Research Centre for Museums and Galleries, Department of Museum Studies, Leicester. Retrieved May 8, 2020 from https://le.ac.uk/rcmg/research-archive/including-museums

ECA (2003). European concept for accessibility. Technical assistance manual. Retrieved April 22, 2020 from http://www.eca.lu/index.php/documents/eucan-documents/132003-european-concept-for-accessibility-2003/file

Eshach, H. (2007). Bridging in-school and out-of-school learning: formal, non-formal, and informal education. Journal of Science Education and Technology, 16(2), 171-190, doi:org/10.1007/s10956-006-9027-1

Falk, J. H., Staus, N., Dierking, L. D., Penuel, W., Wyld, J., \& Bailey, D. (2016). Understanding youth STEM interest pathways within a single community: The Synergies project. International Journal of Science Education, Part B, 6(4), 369-384, doi:10.1080/21548455.2015.1093670

Falk, J., \& Dierking, L. (2013). The museum experience revisited. London - New York: Routledge. 
EDUCATION OF CHILDREN WITH DISABILITIES IN NONFORMAL LEARNING ENVIRONMENTS: A CROSS-DISCIPLINARY APPROACH OF STEAM EDUCATION IN A TECHNOLOGICAL MUSEUM IN GREECE

Fletcher, V. (2013). Museums around the world that enliven our souls: Inclusion through rich experience. Curator, The Museum Journal 56,(3), 297-305, doi:10.1111/cura.12029

Gess, A. H. (2017). STEAM education: Separating fact from fiction. Technology and Engineering Teacher 7 (3), 39-41.

Gibbs, K., Sani, M., \& Thompson, J. (Eds.) (2007). Lifelong learning in museums. A European handbook. Ferrara: Edisaisrl. Retrieved May 8, 2020 from http://online.ibc.regione.emiliaromagna.it/I/libri/pdf/LifelongLearninginMuseums.pdf

Golding, V. (2007). Inspiration Africa!: Using tangible and intangible heritage to promote social inclusion amongst young people with disabilities. In: S. Watson (Ed.) Museums and their communities (pp. 358-372). London: Routledge.

Golden, T., \& Walsh, L. (2013). Play for all at Chicago Children's Museum: A history and overview. Curator, 56 (3), 337-347, doi:10.1111/cura.12032

Grant, J., \& Patterson, D. (2016). Innovative arts programs require innovative partnerships: A case study of STEAM partnering between an Art Gallery and a Natural History Museum. The Clearing House: A Journal of Educational Strategies, Issues and ideas, 89(4), 144-152, doi:10.1080/00098655.2016.1170453

Grajcevci, A., \& Shala, A. (2016). Formal and non-formal education in the New Era. Action Researcher in Education, 7, 119-130.

Gregory, G.H., \& Chapman, C. (2012).Differentiated instructional strategies: One size doesn't fit all ( $3^{\text {rd }}$ ed.). Thousand Oaks, CA: Corwin Press.

Griffin, J. (2007). Students, teachers and museums: Toward an intertwined learning circle. In: J. H. Falk, L.D. Dierking \& S. Foutz (Eds.), In principle, in practice. Museums as learning institutions (pp. 31-42). UK - USA: Altamira Press.

Hansen, A. (2014). The heritage learning framework and the heritage learning outcomes. In: D. Christidou (Ed.), Implementing heritage learning outcomes (pp. 7-24). Östersund: JamtliFörlag, Fornvårdaren 37.

Hayhoe, S. (2013). A practice report of students from a school for the blind leading groups of younger mainstream students in visiting a museum and making multi-modal artworks. Journal of Blindness Innovation and Research 3(2). Retrieved May 10, 2020 from http://eprints.lse.ac.uk/50351, doi:10.5241/2F3-43

Hein, G. (2006). Museum education. In: S. Macdonald (Ed.), A companion to museums studies (pp. 340-352). Oxford: Blackwell Publishing.

Hein, G. (1998). Learning in the museum. London: Routledge.

Hooper-Greenhill, E. (2007). Museums and education. Purpose, pedagogy, performance. London: Routledge.

Hooper-Greenhill, E. (2006).The power of museum pedagogy. In H. H. Genoways (Ed.), Museum philosophy for the twenty-first century (pp. 235-245). United States: Altamira Press. 
Hooper-Greenhill, E. (2004).Measuring learning outcomes in museums, archives and libraries: The Learning Impact Research Project (LIRP). International Journal of Heritage Studies, 10(2), 151-174, doi:10.1080/13527250410001692877

Hooper-Greenhill, E. (2002). Developing a scheme for finding evidence of the outcomes and impact of learning in museums, archives and libraries: the conceptual framework. Research Centre for Museums and Galleries, Department of Museum Studies, Leicester: University of Leicester. Retrieved May 8, 2020 from https://le.ac.uk/rcmg/publications

Hooper-Greenhill, E. (Ed.) (1999). The educational role of the museum. London: Routledge. Hooper-Greenhill, E. (1994). Museum and gallery education. London: Leicester University Press.

Hooper-Greenhill, E., Sandell, R., Moussouri, T., \& O'Riain, H. (2000). Museums and social inclusion-The GLLAM report. Leicester: Research Centre for Museums and Galleries, Department of Museum Studies, University of Leicester. Retrieved May 8, 2020 from https://le.ac.uk/rcmg/publications

Hwang, J., \& Taylor, J. (2016). Stemming on STEM: A STEM education framework for students with disabilities. Journal of Science Education for Students with Disabilities 19 (1), 39-49.

Institute of Museum and Library Services (2009). Museums, Libraries, and 21st century skills (IMLS-2009-NAI-01). Washington, D.C. Retrieved on May 7, 2020 from https://www.imls.gov/assets/1/AssetManager/21stCenturySkills.pdf

Isari, F., \& Pourkos, M. (2015).Qualitative research methodology [ebook]. Athens: Hellenic Academic Libraries Link (in Greek). Retrieved on May 15, 2020 from http://hdl.handle.net/11419/5826

Israel, M., Maynard, K., \& Williamson, P. (2013). Promoting Literacy-Embedded, Authentic STEM Instruction for Students with Disabilities and other Struggling Learners. Teaching Exceptional Children, 45(4), 1825. doi.org/10.1177/004005991304500402

Kanari, Ch. (2015). Museums and individuals with visual disabilities: Issues of access and education in museums for children with visual disabilities. (Doctoral dissertation, University of Thessaly). Retrieved May 8, 2020 from https://www.didaktorika.gr/eadd/handle/10442/36292, (In Greek).

Kanari, Ch., Argyropoulos, V., \& Filippatou, D. (2017). Social inclusion and museums. Special Education teachers' perceptions regarding museum and social inclusion. On line International Journal Museum Edu 5, 107-133 (In Greek). Retrieved May 8, 2020 from http://museumedulab.ece.uth.gr/main/sites/default/files/A.\%206..pdf

Kanari, H., \& Argyropoulos, V. (2014). Museum educational programmes for children with visual disabilities. The International Journal of the Inclusive Museum 6(3), 13 26.

Kanari, H. \& Vemi, V. (2012). Museum educational programs for children with disabilities. Current practices in Greece. In: Chr. Prachalias (Ed.), Proceedings of the 
EDUCATION OF CHILDREN WITH DISABILITIES IN NONFORMAL LEARNING ENVIRONMENTS: A CROSS-DISCIPLINARY APPROACH OF STEAM EDUCATION IN A TECHNOLOGICAL MUSEUM IN GREECE

8th International Conference of Education, Samos Island, 5-7 July, 2012 (pp. 984-989).

Greece Research of Training Institute of the East Aegean (INEAG), Greece.

Khine, M. S., \& Areepattamannil, S. (Eds) (2019). STEAM Education: theory and practice. Cham, Switzerland: Springer Nature Switzerland AG

Ko, Y., An, J., \& Park, N. (2012) Development of computer, math, art convergence education lesson plans based on smart grid technology. In: T. Kim et al. (Eds.), Communications in computer and information Science, vol 339 (pp. 109-114). Berlin, Heidelberg: Springer Berlin, Heidelberg, doi.org/10.1007/978-3-642-35264-5_15

Land, M. H. (2013). Full STEAM ahead: The benefits of integrating the arts into STEM. Procedia Computer Science, 20, 547-552, doi.org/10.1016/j.procs.2013.09.317

Liao, C. (2016). From interdisciplinary to transdisciplinary: An Arts-integrated approach to STEAM education. Art Education, 69(6), 44-49, doi:10.1080/00043125.2016.1224873

Louvi, A. (2007). Thematic technological museums: The museum network of the Piraeus Bank Group Cultural Foundation. Tetradia Mouseiologias, 4, 40-44 (in Greek).

Lurio, A. (2016). Engaging children with autism at historical sites: Developing an audience-appropriate curriculum. Journal of Museum Education, 42(3), 165-173, doi: $\underline{10.1080 / 10598650.2016 .1193315}$

Mace, R. (1988). Universal design: Housing for the lifespan of all people. U.S.: Department of Housing and Urban Affairs Office of Public Affairs Publication. Retrieved April 22, 2020 from https://mn.gov/mnddc/parallels2/pdf/80s/88/88HFL-UDS.pdf

Mace, R. L., Hardie, G. L., \& Place, J. P. (1996). Accessible environments. Towards Universal Design. USA: Raleigh, NC: North Carolina State University. Retrieved April 22, 2020

from https://projects.ncsu.edu/ncsu/design/cud/pubs p/docs/ACC\%20Environments.p $\underline{\mathrm{df}}$

Malley, S. M., \& Silverstein, L. B. (2014). Examining the intersection of arts education and Special Education. Arts Education Policy Review, 115(2), 39-43, doi:10.1080/10632913.2014.883894

Maslyc, J. (2016). STEAM makers: Fostering creativity and innovation in the elementary classroom. Thousand Oaks, CA: Corwin Press.

Melber, L. M., \& Brown, K. D. (2008). Not like a regular science class: informal science education for students with disabilities. The Clearing House: A Journal of Educational Strategies, Issues and Ideas, 82(1), 35-39, doi:10.3200/TCHS.82.1.35-39

Miles, M., \& Huberman, A. (1994). An expanded sourcebook: Qualitative data analysis. California.

Mouliou, M. (2015).The Museum as quality, experience, city brand and soft power. Examples from the international and national museum practice. In: Poulios et al. (Eds), Cultural management, local community and sustainable development (pp. 74-95), [ebook]. Athens: Hellenic Academic Libraries Link (in Greek). Retrieved April 22, 2020 from http://hdl.handle.net/11419/2394 
Moussouri, T. (2002). A context for the development of learning outcomes in museums, archives and libraries. Research Centre for Museums and Galleries, Department of Museum Studies, Leicester: University of Leicester. Retrieved May 11, 2020 from https://le.ac.uk/rcmg/publications

Moss, P. A. (2003). Reconceptualizing validity for classroom assessment. Educational Measurement: Issues and Practice, 22(4), 13-25, doi.org/10.1111/j.17453992.2003.tb00140.x

Nikolaraizi, M., Kanari, C., \& Marschark, M. (2020). Tickets for the inclusive museum. Accessible opportunities for nonformal learning by Deaf and hard-of-hearing individuals. In: M. Marschark \& H. Knoors (Eds), The Oxford handbook in deaf studies in learning and cognition (pp. 391-406). Oxford University Press.

Nikolaraizi, M. (2013). Universal Design for Learning and Differentiated Instruction: their role for students with disabilities and/or special educational needs. In: S. Padeliadou \& D. Filippatou (Eds), Differentiated Instruction. Theoretical approaches and teaching practices (pp. 99-120). Athens: Pedio (in Greek).

Nikonanou, N. (2010). Museum Education. From theory to practice. Athens: Patakis (in Greek).

Norqvist, L., \& Leffler, E. (2017). Learning in non-formal education: is it "youthful" for youth in action? International Review of Education, 63(2), 235-256, doi.org/10.1007/s11159-017-9631-8

Pearson, A., \& Aloysious, C. (1994). The big foot. Museums and children with learning difficulties. London: Trustees of the British Museum. British Museum Press.

Perignat, E., \& Katz-Buonincontro, J. (2019). STEAM in practice and research: An integrative literature review. Thinking Skills and Creativity, 31, 31-43, doi:10.1016/j.tsc.2018.10.002

Pisha, B., \& Coyne, P. (2001). Smart from the start: The promise of universal design for learning. Remedial and Special Education, 4, 197-203, doi:10.1177/074193250102200402

Quigley, C. F., Herro, D., \& Jamil, F. M. (2017). Developing a conceptual model of STEAM teaching practices. School Science and Mathematics, 117(1-2), 1-12, doi:10.1111/ssm.12201

Rappolt-Schlichtmann, G., \& Daley, S. G. (2013). Providing access to engagement in learning: The potential of Universal Design for Learning in museum design. Curator, 56, 307-321, doi.org/10.1111/cura.12030

Resource: the Council for Museums, Archives and Libraries (2001). Disability Directory for Museums and Galleries, Retrieved April 20, 2020 from https://www.accessibletourism.org/resources/uk museumsandgalleries disability directory pdf 6877.pdf

Riviou, K., Kouroupetroglou, G., \& Oikonomidis, N. (2015). Design of educational activities based on the principles of Universal Design for Learning. In: S. Pantazis, E. Maraki, M. Kadianaki \& E. Beladakis (Eds), Proceedings "The Contemporary School 
through the Prism of Humanities and Social Sciences: From Theory to Practice", 24-26 April 2015 (pp. 442- 451), Iraklion, Crete: IAKE (in Greek).

Romi, S., \& Schmida, M. (2009). Nonformal Education: A major educational force in the postmodern era. Cambridge Journal of Education, 39, 257-273, doi:10.1080/03057640902904472

Rosenberg, F., Schroder, L., \& Wheelock F. P. (2003).Museum and school collaborations. In: E. S. Axel \& N. S. Levent (Eds.), Art beyond sight. A resource guide to art. Creativity and visual impairment (pp. 364-373). New York: AFB Press.

Sandell, R. (2003). Social inclusion, the museum and the dynamics of sectoral change. Museum and Society 1(1), 45-62.

Sandell, R. (2002). Museums and the combating of social inequality: Roles, responsibilities, resistance. In: R. Sandell (Ed.), Museums, society, inequality (pp. 323). London: Routledge.

Servilio, K. L. (2017). Cases on STEAM education in practice: Differentiated instruction. In: J. Bazler \& M. Van Sickle (Eds.), Cases on STEAM education in practice (pp. 319334). USA: IGI Global.

Shelley, R. (2015). Language at play in the museum: The case of Belgium and her multilingual arts and heritage institutions. Museums $\mathcal{E}$ Social Issues, 10(1), 18-34, doi: $10.1179 / 1559689314 Z .00000000030$

Shepherd, H. (2009). Inclusion and museums: Developing inclusive practice. British Journal of Special Education, 36(3),140-145, doi:10.1111/j.1467-8578.2009.00437.x

Shibley, I. A. (2006). Interdisciplinary team teaching: Negotiating pedagogical differences, College Teaching, 54(3), 271-274, doi: 10.3200/CTCH.54.3.271-274

Sickle, M. Van, \& Bazler, J. (Eds.) (2017). Introduction. In: J. Bazler \& M. Van Sickle (Eds.), Cases on STEAM education in practice (pp. xviii-xxx). USA: IGI Global.

Spandagou, I. (2011). The use of museums in inclusive education of children with disabilities. In: D. Kalesopoulou (Ed.), Child and education in museums: Theoretical orientations, pedagogical practices (pp. 113-124). Athens: Patakis (in Greek).

Staus, N. L., Falk, J. H., Penuel, W., Dierking, L., Wyld, J., \& Bailey, D. (2020). Interested, disinterested, or neutral: Exploring STEM interest profiles and pathways in a lowincome urban community. Eurasia Journal of Mathematics, Science and Technology Education, 16(6), em1853.doi.org/10.29333/ejmste/7927

Souliotou, A. Z. (2016). The importance of including the Arts in STEM education, Hellenic Conference on Innovating STEM Education [HiSTEM 2016], National and Kapodistrian University of Athens. (in Greek) Retrieved June 23, 2020 from: https://stemeducation.upatras.gr/histem2016/

Sousa, D. A., \& Pilecki, T. (2013). From STEM to STEAM: Using brain-compatible strategies to integrate the arts. Thousand Oaks, CA: Corwin Press.

Tomlinson, C. A. (2014). The differentiated classroom: Responding to the needs of all learners (2nd ed.). Alexandria, VA: ASCD.

Tomlinson, C. A. (2001). How to differentiate instruction in mixed-ability classrooms (2nd ed). Alexandria, VA: ASCD. 
Tomlinson, C. A., \& Allan, S. D. (2000). Leadership for differentiating schools and classrooms. Alexandria, VA: ASCD.

Tranter, R., \& Palin, N. (2004). Including the excluded: An art in itself. Support for Learning, 19 (2), 88-95, doi:10.1111/j.0268-2141.2004.00326.x

UNESCO (2015). Rethinking education. Towards a global common good? Retrieved June 23, 2020 from: http://unesdoc.unesco.org/images/0023/002325/232555e.pdf

UNESCO-UIS (United Nations Educational, Scientific, and Cultural Organization. UNESCO Institute of Statistics) (2012). The international standard classification of education ISCED 2011. Montreal: UNESCO-UIS. Retrieved June 23, 2020 from: http://uis.unesco.org/sites/default/files/documents/international-standardclassification-of-education-isced-2011-en.pdf

Vartiainen, H., \& Enkenberg, J. (2013). Learning from and with museum objects: design perspectives, environment, and emerging learning systems. Education Technology Research and Development, 61(4), 841-862, doi:org/10.1007/s11423-013-9311-8

Vemi, V., \& Kanari, H. (2008). School teachers and museum education: A key factor in expanding the inclusive character of museums. The International Journal of the Inclusive Museum 1, 1-8.

Wapner, J. (2013). Mission and low vision: A visually impaired museologist's perspective on inclusivity. Disability Studies Quarterly 33(3). Retrieved April 20, 2020 from https://dsq-sds.org/article/view/3756, doi:10.18061/dsq.v33i3.3756

Weisen, M. (2008). How accessible are museums today? In H. J. Chatterjee (Ed.), Touch in museums. Policy and practice in object handling (pp. 243-252). Oxford-New York: BERG.

Yakman, G. (2008). ST $@ M$ Education: an overview of creating a model of integrative education. Pupils Attitudes Towards Technology 2008 Annual Proceedings. Netherlands.

Zayyad, M. (2019). STEAM Education for students with specific learning disorders. In: W. Wu \& S. Alan (Eds), Research highlights in education and science 2019 (pp. 31- 42). ISRES Publishing. Retrieved May 8, 2020 from https://www.isres.org/books/RHES2019 01-01-2020.pdf. 
Creative Commons licensing terms

Authors will retain the copyright of their published articles agreeing that a Creative Commons Attribution 4.0 International License (CC BY 4.0) terms will be applied to their work. Under the terms of this license, no permission is required from the author(s) or publisher for members of the community to copy, distribute, transmit or adapt the article content, providing a proper, prominent and unambiguous attribution to the authors in a manner that makes clear that the materials are being reused under permission of a Creative Commons License. Views, opinions and conclusions expressed in this research article are views, opinions and conclusions of the author(s). Open Access Publishing Group and European Journal of Alternative Education Studies shall not be responsible or answerable for any loss, damage or liability caused in relation to/arising out of conflict of interests, copyright violations and inappropriate or inaccurate use of any kind content related or integrated on the research work. All the published works are meeting the Open Access Publishing requirements and can be freely accessed, shared, modified, distributed and used in educational, commercial and non-commercial purposes under a Creative Commons Attribution 4.0 International License (CC BY 4.0). 